\title{
Early Childhood Teacher Professionalism Based on Academic Qualifications and Work Experience
}

\author{
Syafrimen Syafril ${ }^{{ }_{1}}$, Devi Kurniawati ${ }^{2}$, Agus Jatmiko ${ }^{3}$, Ida Fiteriani ${ }^{4}$, Cahniyo Wijaya \\ Kuswanto $^{5}$ \\ Pendidikan Islam Anak Usia Dini, Universitas Islam Negeri Raden Intan Lampung \\ DOI: $\underline{10.31004 / o b s e s i . v 5 i 2.937}$
}

\begin{abstract}
This study aims to analyze the professionalism of early childhood teachers in mastering the material based on academic qualifications and work experience. The approach to research sequential explanatory mixed methods design; The first phase using descriptive quantitative involving 57 teachers, data were collected through a questionnaire, analyzed descriptively and inferentially assisted by SPSS version 26.0. The second phase used a holistic multi-case study involving six school principals, data were collected through in-depth interviews and analysis documents, analyzed interactively with the assistance of Nvivo 12.0. The results showed that there was no difference in teacher professionalism based on academic qualifications and work experience. The second phase finds; teacher professionalism is not only influenced by academic qualifications and work experience, teacher professionalism is also influenced by various professional trainings that have been attended, and prospective teachers who choose the early childhood education programs major do not fully understand the substance of the lecture program related to their professionalism.
\end{abstract}

Keywords: early childhood teacher professionalism; academic qualifications; work experience; mastery of teaching materials

\begin{abstract}
Abstrak
Penelitian ini bertujuan menganalisis profesionalisme guru PAUD dalam menguasai materi berdasarkan kualifikasi akademik dan pengalaman kerja. Pendekatan penelitian explanatory sequential mixed methods design; fase pertama menggunakan kuantitatif deskriptif melibatkan 57 orang guru, data dikumpulkan melalui kuesioner, dianalisis secara deskriptif dan inferensial berbantukan SPSS versi 26.0. Fase kedua menggunakan holistic multi-case study melibatkan enam orang kepala sekolah, data dikumpulkan melalui in-depth interview dan dokumen analisis, dianalisis secara interaktif berbantukan Nvivo 12.0. Hasil penelitian menunjukan tidak terdapat perbedaan profesionalisme guru berdasarkan kualifikasi akademik dan pengalaman kerja. Fase kedua mendapati; profesionalisme guru tidak hanya dipengaruhi oleh kualifikasi akademik dan pengalaman kerja, dipengaruhi juga oleh berbagai pelatihan profesional yang pernah diikuti, dan calon guru yang memilih jurusan PAUD kurang memahami sepenuhnya substansi program perkuliahan terkait profesionalisme mereka.
\end{abstract}

Kata Kunci: profesionalisme guru paud; kualifikasi akademik; pengalaman kerja; penguasaan materi ajar

Copyright (c) 2020 Syafrimen Syafril, Devi Kurniawati, Agus Jatmiko, Ida Fiteriani, Cahniyo Wijaya Kuswanto,

$\triangle$ Corresponding author:

Email Address: syafrimen@radenintan.ac.id (Bandar Lampung, Indonesia)

Received 1 December 2020, Accepted 21 December 2020, Published 30 December 2020 


\section{INTRODUCTION}

Based on various pieces of literature, a professional teacher in early childhood education programs is someone who has expertise and abilities in his field. This is characterized by an attitude that shows one's expertise in serving and contributing to the profession he is engaged in (Fonsén and Ukkonen-Mikkola, 2019: 8; Turner, 2016: 14). Some literatures mention that the characteristics of teacher professionalism can also be seen through their knowledge, abilities, and mastery of the profession (Kunandar, 2007: 47; Li et al., 2010: 156; Wisnarni, 2018: 33). This applies to the teachers who are at the early childhood education level. This literature is reinforced by the view that the professionalism of a teacher is characterized by self-regulation, special knowledge, and adherence to the code of ethics formulated by the profession (Evetts, 2006: 140; Nolan and Molla, 2017: 11; Svensson, 2006: 588; Woodrow, 2007: 236). Conversely, other literature says that early childhood teachers who do not master various teaching materials, media, and methods and who have not taken advantage of technological advances are teachers who do not have a professional attitude (Veisson and Kabaday, 2018: 11).

Several pieces of literature connect teacher professionalism to academic qualifications and work experience (Igberadja, 2016: 36; Nofriyanti and Nurhafizah, 2016: 678). Academic qualifications and work experience are the determining factors for teacher professionalism (Utami and Kartini, 2017: 182). Teacher professional qualifications are based on programs and academic degrees, which are assumed to affect teachers' mastery of teaching material (EastonBrooks and Davis, 2009: 2; Kamila, 2017: 42; Manning et al., 2017: 20). The academic qualifications of early childhood teachers are described in National Education Ministry Regulation No. 16 of 2007 on Academic Qualification Standards and Teacher Competencies, which states "Teachers in PAUD/TK/RA must have a minimum educational qualification of diploma four (D4) or Bachelor (S1) in early childhood education or psychology obtained from an accredited study program". Various kinds of literature reveal that the work experience of early childhood teachers also affects the professionalism of teachers in mastering teaching materials (Idika and Onuoha, 2018: 100; Mitits, 2018: 28; Suwarni, 2011: 123), as the disposition of professionalism is obtained automatically from work experience in the field (Creasy and Hall, 2015: 23). The more experienced a teacher is, the higher the professionalism of the teacher in mastering the material (Isari et al., 2017: 22; Kholifiatin et al., 2020: 769).

Based on statistical data from the Ministry of Education and Culture of Indonesia, early childhood teachers with graduates $>\mathrm{S} 1$ are $72.81 \%$, and $27.19 \%$ are graduates $<\mathrm{S} 1$. meanwhile, early childhood teachers majoring in early childhood education are $48.20 \%$, non-early childhood education and no department are $51.80 \%$. In Lampung, early childhood teachers with graduates $>\mathrm{S} 1$ are $61.86 \%$ and $38.14 \%$ for graduates <S1. meanwhile, $40,09 \%$ of early childhood teachers come from the early childhood education department and 59.91\% from the non- early childhood education department and not specified (nasrun et al., 2018: 29). based on the data above, there are still many early childhood teachers in Indonesia who do not have the qualifications as early childhood teachers as in the field, and it is often found that some teachers do not teach according to their fields (Sholihah et al., 2020: 2; Yusnita et al., 2018: 124). This is very much found in early childhood education itself (Yuslam et al., 2017: 152). Whereas according to Creasy \& Hall (2015: 23), implementing the learning process according to the ability in the field is the focus and key of teacher professionalism, Mutohar also agrees with this opinion (Mutohar, 2013: 152).

Research related to teacher professionalism has been widely conducted by various previous researchers, including teacher professionalism and its relation to multimedia technology (Gluzman et al., 2018), teacher professionalism associated with the workshop (Johannes, 2018), teacher professionalism in the field of dual structure (Nairz-Wirth and Feldmann, 2019), the effect of teacher professionalism on teacher-child interactions (Her and Kim, 2018), the relationship between individual innovation and teacher professionalism (Parlar and Cansoy, 2017) and science-based and pedagogical professionalism (Dodillet et al., 
2019). However, relatively few researches on the professionalism of early childhood teachers related to academic qualifications and work experience have been conducted. Researches that are similar to this research tried to see the professionalism of early childhood teachers, especially about the efforts of teachers in developing the Education Unit Level Curriculum based on the 2013 Curriculum (Danur and Nurhafizah, 2019), teacher professionalism to improve the quality of learning (Bali Literature, 2016), teacher professionalism based on academic qualifications and tenure at the primary and secondary education levels (Alamsyah et al., 2020; Putri Komalasari, 2014). Meanwhile, according to some previous literature, teacher professionalism is essential to be developed to motivate and improve early childhood learning outcomes (Armani and Margunani, 2017; Marlina et al., 2020; Puspitasari et al., 2021; Syaifulloh, 2017). In fact, this research tries to analyze the professionalism of Early Childhood Teachers in mastering teaching materials based on academic qualifications and work experience.

\section{METHODOLOGY}

This study uses a mixed approach with an sequential explanatory mixed methods design. This approach is characterized by collecting and analyzing quantitative data in the first stage and qualitative collection in the second stage (Creswell, 2017: 4; Sugiyono, 2011: 409). The first stage of this research uses descriptive quantitative involving 57 early childhood teachers in Sumber Jaya sub-district, West Lampung, taken through a total sampling technique. The data were collected using a questionnaire on Teacher Professionalism in Mastering Teaching Materials, which is derived from the theory of Maion Edmon, Santrock, Johnson, Jerry H. Makawimbang, and Suryasubrata. Some steps to make a questionnaire are (i) deriving research variables according to theory (making the instrument grid), (ii) determining the purpose of the questionnaire, (iii) determining the type of question, (iv) determining the scale for measuring the respondent's response, (v) determining the respondent from the questionnaire (vi) adjusting the language, type, and form of the questionnaire, and (vii) validating the questionnaire.

The validity and reliability of the instrument were tested before the questionnaire was distributed, 32 statements submitted were 25 valid and reliable statements, and seven statements were less valid and less reliable. Then the data analysis was carried out descriptively on the frequency of the teacher's answer score on the questionnaire, and twoway ANOVA (Analysis of Variance) parametric inferential data analysis assisted by SPSS v.26.0 software, this test is to see the effect of the individual and the combination of two independent variables on one dependent variable (Pallant, 2007: 257). provided that the data is normally distributed and homogeneous (Tabachnick, nd,: 221).

In the second stage, the researcher used a qualitative holistic multi-case study design. In-depth interview data was conducted with six school principals as research subjects selected by purposive sampling to provide value and information about early childhood teachers and researchers' professionalism as the key instrument of this study. Document analysis is carried out on diploma, certificate, and teacher performance assessment documents. Data analysis was carried out interactively, namely: collecting, reducing, presenting, and drawing conclusions on existing data using the Nvivo 12.0 software. This stage is carried out because in the sequential explanatory approach, the results of qualitative data are built on the results of quantitative data and are used to explain and describe quantitative data (Creswell, 2017: 4; Ivankova et al., 2009: 5) to strengthen the previous findings, more clearly the design in this study can be seen in chart 1 . 


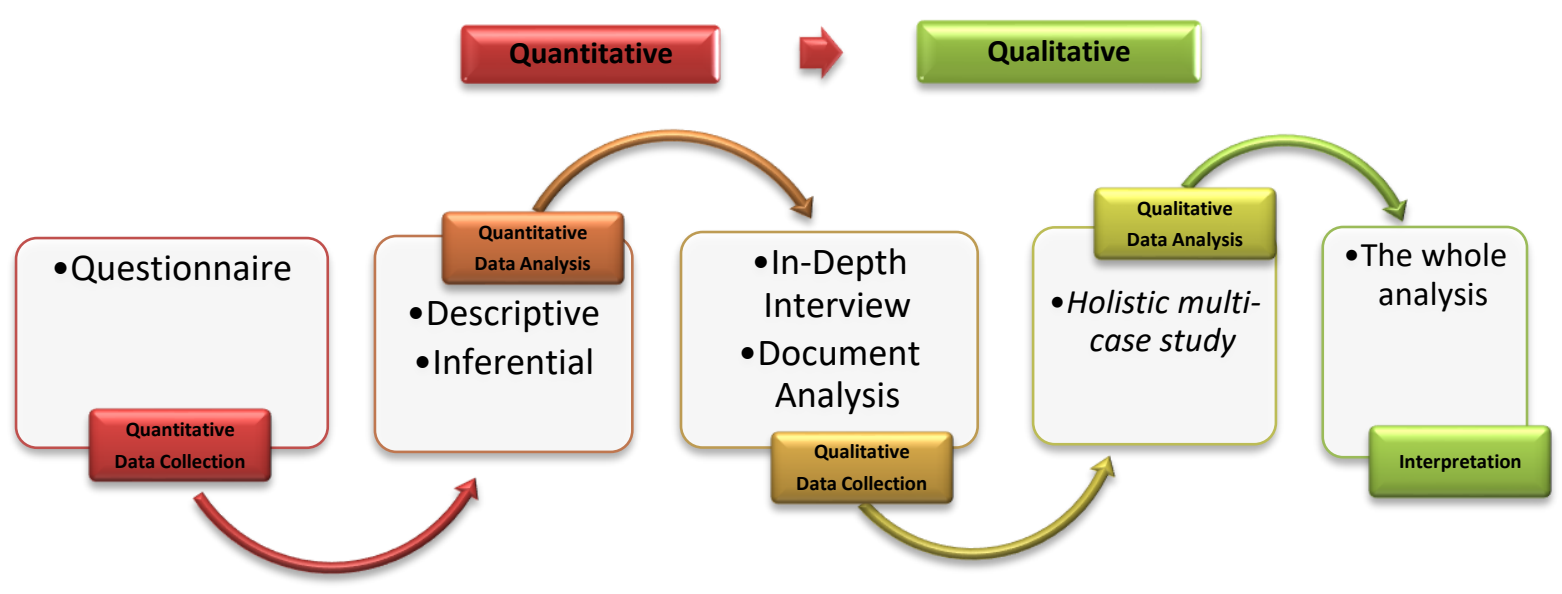

Chart 1. Sequential Explanatory Design

\section{RESULTS AND DISCUSSION}

The basis for determining the interpretation for the first research refers to the Penilaian Acuan Patokan (PAP) which is also called Criterion Referenced Evaluation (CRE) or Criterion Referenced Measurement (CRM), which was first used by Galser and Klaus (1962). The results showed that the teachers studied their overall professionalism were at a good level More clearly can be seen in the table 1 .

Table 1. Teacher Professionalism in Mastering Teaching Materials

\begin{tabular}{lccl}
\hline \multicolumn{1}{c}{ Score } & Frequency & Percentage & \multicolumn{1}{c}{ Interpretation } \\
\hline $106-125$ & 10 & $17.54 \%$ & Very high \\
$91-105$ & 42 & $73.69 \%$ & High \\
$81-90$ & 5 & $8.77 \%$ & Enough \\
$71-80$ & - & $0 \%$ & Low \\
$<71$ & - & $0 \%$ & Very low \\
\hline Total & 57 & $100 \%$ & \\
\hline
\end{tabular}

The results of the second research concluded that there was no difference in the professionalism of early childhood teachers in mastering teaching materials based on academic qualifications and work experience, this can be seen in the table 2 .

Table 2. Tests of Between-Subjects Effects

Dependent Variable: Early Childhood Teacher Professionalism

\begin{tabular}{lrrrrr}
\hline \multicolumn{1}{c}{ Source } & $\begin{array}{c}\text { Type III Sum } \\
\text { of Squares }\end{array}$ & df & $\begin{array}{c}\text { Mean } \\
\text { Square }\end{array}$ & F & \multicolumn{1}{c}{ Sig. } \\
\hline Academic Qualifications & 153,137 & 3 & 51,046 & 1,202 & 0.321 \\
Work experience & 190,038 & 3 & 63,346 & 1,492 & 0.231 \\
Academic Qualifications * & 305,285 & 9 & 33,921 & 0.799 & 0.619 \\
Work Experience & & & & &
\end{tabular}

The results of the above research confirm that early childhood teachers basically have good professionalism. So it can be seen that the professionalism of early childhood teachers is very important for teachers to improve their quality and the quality of education (Fonsén and Ukkonen-Mikkola, 2019: 6; Schachter et al., 2019: 1) where education can develop the maximum potential of children (Pahrudin et al., 2018: 83). In addition, teacher professionalism affects the learning process in the classroom (Jensen and Rasmussen, 2018: 1; Sintia et al., 
2019:1-2; Ubabuddin, 2018: 32). Providing a good learning process can make it easier for children to achieve maximum learning goals (Syafril et al., 2020: 2). This is because professionalism, teaching skills, and education quality are influenced and predicted by teachers' academic qualifications and work experience (Ackerman, 2005: 11; Putri Komalasari, 2014: 1; Sethi et al., 2018: 567; Setiawan, 2017: 39; Snider and Fu, 1990: 75; Vartuli, 1999: 489).

Own experience is based on higher education and is not only teacher-centered but also child-centered (Shipton, 2020: 14). This can be used as a way of educational development. So do not be surprised if the experience (soft skills and hard skills) is real (Fahmi and Hariasih, 2016: 81) and contributes to improving teacher professionalism. The experience that teachers have is important as it contributes to the success of early childhood education itself (Nusran et al., 2018: 80). So that early childhood teachers should have a good teaching experience.

Even so, the qualifications possessed by teachers are not the only cause of teacher professionalism in carrying out the learning process and improving early childhood learning outcomes (Easton-Brooks and Davis, 2009: 4; George et al., 2005: 418; Igberadja, 2016: 36; Nusa, 2020: 31-32; Phillips et al., 2000: 477). This is in line with the results of Toh et al.'s research, namely that academic qualifications and teaching experience are not related to teacher professionalism (Barida and Muarifah, 2019: 22; Toh et al., 1996: 231).

In addition to the results of quantitative analysis, the qualitative results are categorized into three aspects that affect the professionalism of early childhood teachers, namely (i) teacher professionalism is not only influenced by academic qualifications and work experience, (ii) teacher professionalism is also influenced by various professional trainings that have been attended, and (iii) prospective teachers who choose the early childhood education programs major do not fully understand the substance program related to their professionalism. Further data analysis results can be seen in the image 1.

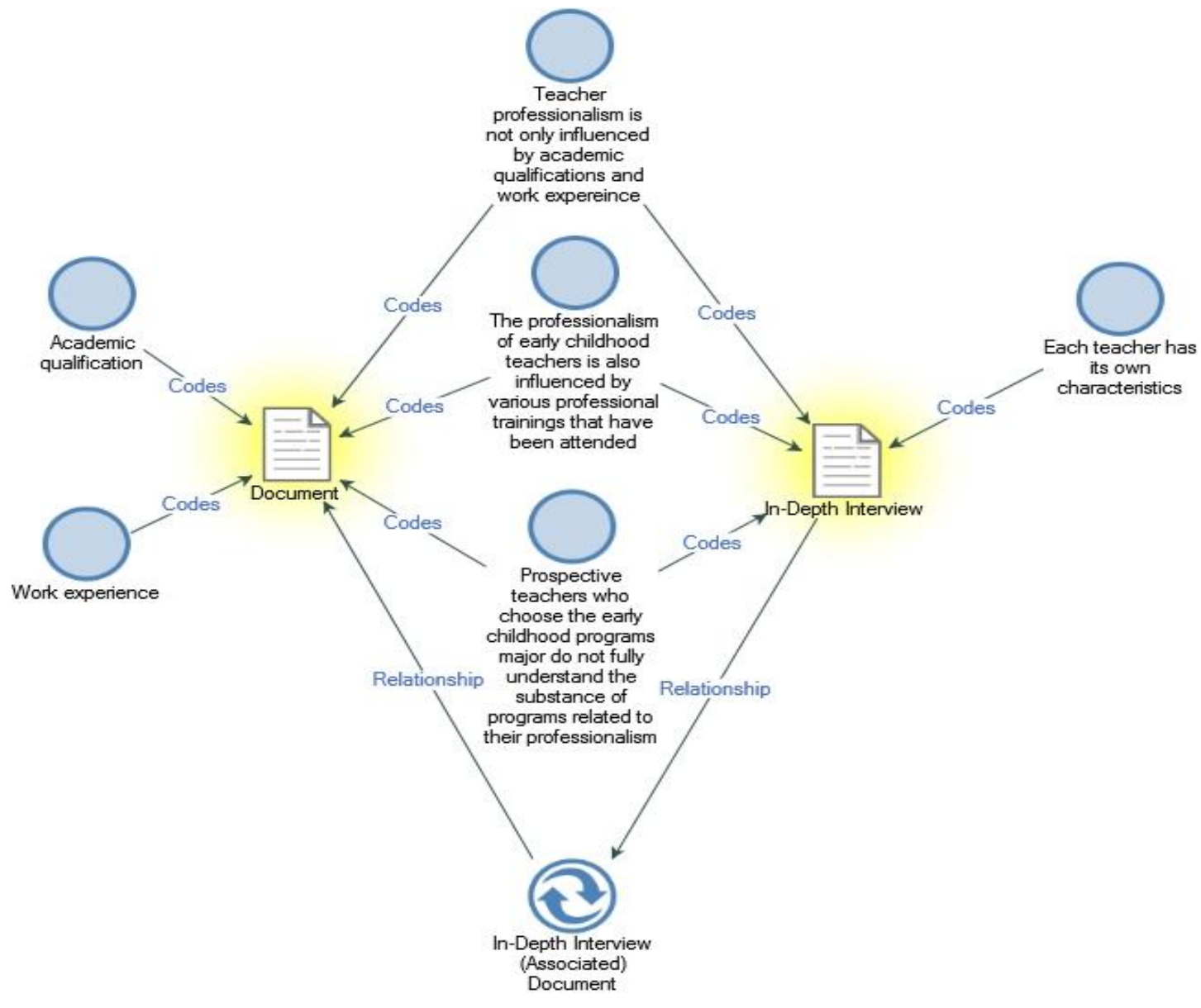

Figure 2. Data triangulation 
Detailed information on the results of in-depth interviews to show other aspects that affect the professionalism of early childhood teachers has been recapitulated on the second mind map image.

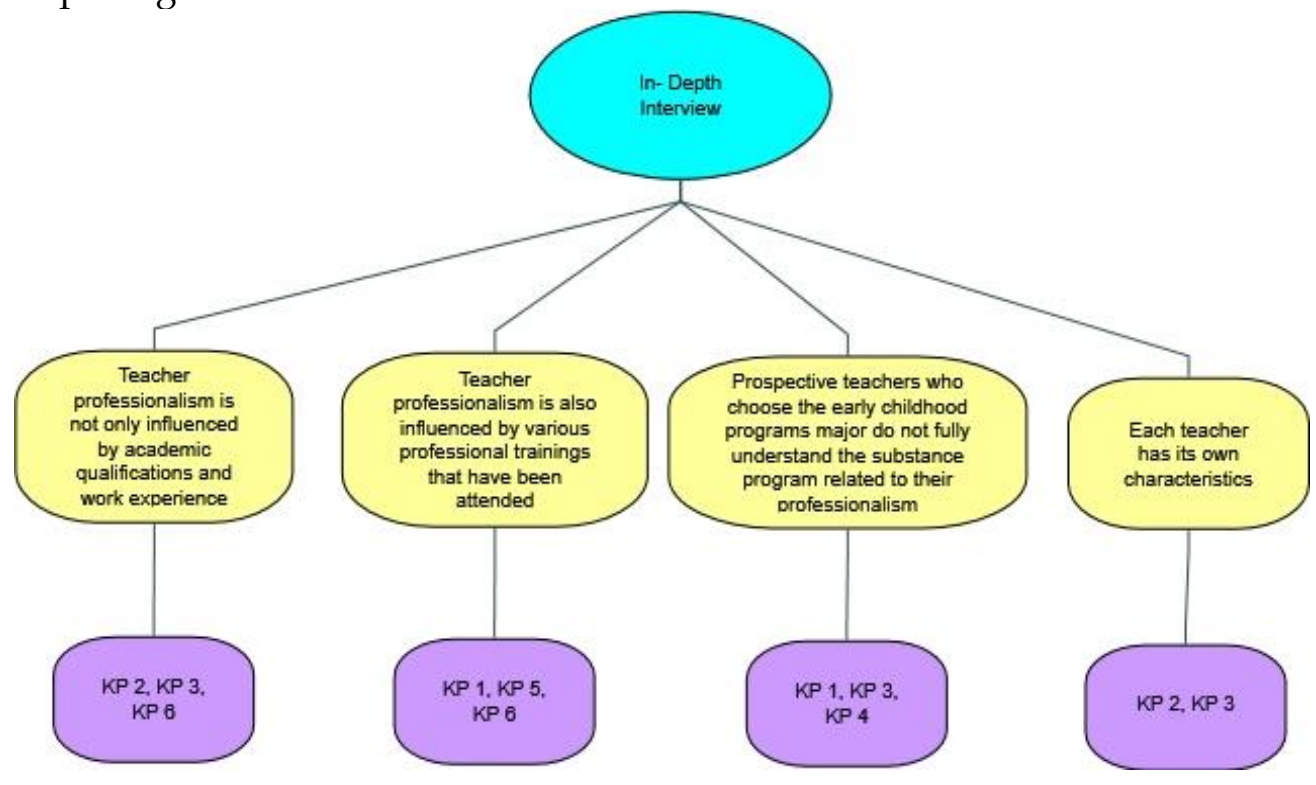

Figure 2. Aspects Affecting Teacher Professionalism

Aspects that affect professionalism obtained from the interview results are: The first aspect according to the Principal of early childhood education (KP) 2, 3 and 6 is that teacher professionalism is not only influenced by academic qualifications and work experience; Second, KP 1, 5 and 6 believe that teacher professionalism is also influenced by the various professional trainings that have been attended by teachers continuously; Third, KP 1, 3 and 4 agree that prospective teachers who choose the early childhood education department do not fully understand the substance of the lecture program related to their professionalism; Fourth, each teacher has its own characteristics which were expressed by the Principals of early childhood education 2 and 6 schools.

However, the results of the in-depth interviews with the early childhood education school principal must be in accordance with the existing documents in the institution itself. The professionalism of teachers can be recorded systematically. The results of the analysis documents can be seen in the third mind map image.

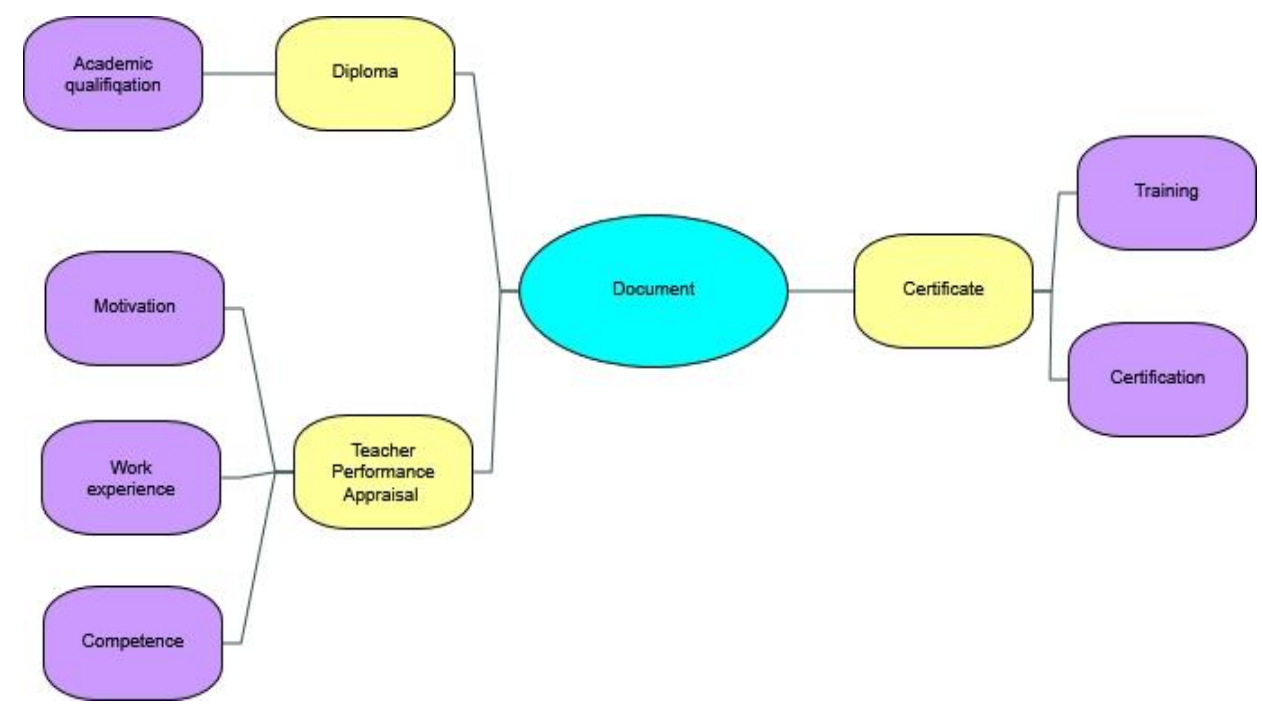

Figure 3. Analysis Documents 
Many efforts must be made to improve the professionalism of early childhood teachers, but this requires government policies to develop teacher human resources (Muhadjir, 1992: 119). The results of the analysis of this study confirm that there is no difference in the professionalism of early childhood teachers in mastering teaching materials based on academic qualifications and years of service. This shows that many aspects affect teacher professionalism, both from within and outside the teacher himself (Kaya and Gödek, 2016: 1; Kusmaryani et al., 2016: 707).

Some aspects must also be considered in assessing teacher professionalism. These aspects are personality, salary, length of office, training, competence, principal leadership, work climate, support (family, morals, and costs), teaching motivation and interest in learning, availability of learning resources and media, and teacher mastery of the process. and teaching implementation (Danil, 2009: 36-37; Farida et al., 2020:2; Nurhayati, 2006: 68; Yawan, 2016: 184). In addition, other aspects such as gender and years of service also cause differences in the professionalism of early childhood teachers (Arien Majidah RH et al., 2019: 518) which continues to play an integral role in the world of education (Easton-Brooks and Davis, 2009: 2; Lee and Lee, 2020: 1).

Through various trainings, early childhood teachers have the opportunity to learn to continue to substantially improve their quality as a guarantee (Rahayu, et al., 2018:3) in order to be considered professional and qualified. According to Nusa (2020: 27), certified teachers have better performance than those who are not certified. This is because teachers must have the ability and competence to be proactive teachers and understand skills in managing their own behavior (Syafril, et al., 2017: 1678). The improvement of teachers' self quality follows the training process that is followed (Kusumawardhani, 2017: 609).

Students need understanding, interest, and motivation to optimally carry out their education (Syafril, et al., 2017: 6). The community's assessment of early childhood education is the background of the nation's future view of early childhood education. Many early childhood education student-teachers think that the substance in early childhood education courses is less important, which certainly affects their readiness to become professional teachers. Though, early childhood education graduates are not guaranteed to get skills in their fields (Erlina et al., 2016: 7). Nevertheless, the formation of professional early childhood teachers must start when a teacher is still a prospective educator (Fenech et al., 2010: 90; Syafril, et al., 2017: 6), in order to produce quality teachers and make quality students as well (Arfah and Muhidin, 2018: 183; Ishak et al., 2003: 5), because teachers play an important role in learning in reducing and increasing children's learning motivation (Syafril, et al., 2020: 21; Syafril, et al., 2020: 953) and qualified teachers are able to convey knowledge consistently and attractively as the expression from Rahayu, et al., (2018: 6).

\section{CONCLUSION}

One of the professionalism of a teacher can be seen through the seriousness of the teacher in preparing good teaching materials before learning is carried out. The findings of this study found that teacher professionalism is not only influenced by academic qualifications and work experience. In fact, the professionalism of teachers needs to be seen from various aspects that influence the improvement of the quality of early childhood education at present and in the future.

\section{ACKNOWLEDGEMENT}

The author would like to express his gratitude to all parties who have contributed to this research, especially teachers and school management who have provided comprehensive data to complete this research. 


\section{REFERENCES}

Ackerman, D. J. (2005). Getting teachers from here to there: Examining issues related to an early care and education teacher policy. Early Childhood Research and Practice, 7(1), 1-26.

Alamsyah, M., Ahmad, S., \& Harris, H. (2020). Pengaruh Kualifikasi Akademik dan Pengalaman Mengajar terhadap Profesionalisme Guru. Journal of Education Research, 1(3), 1830187. https://doi.org/10.37985/joe.v1i3.19

Arfah, M., \& Muhidin, S. A. (2018). Hubungan kompetensi profesional guru dengan hasil belajar siswa SMK bidang keahlian bisnis dan manajemen di kota Bandung (studi pada SMK Bina Sarana Cendikia Bandung , SMK Kiansantang Bandung , SMK Muhammadiyah 4 Bandung, SMK Mutiara Bandung dan SMK YPK. 3(2), 182-189. https:// doi.org/10.17509/jpm.v3i2.11763

Arien Majidah RH, R., Ekawati, \& Wahyuni, E. (2019). Analisis Pengaruh Faktor Demografi, Upah Kerja, Motivasi Kerja Dan Stres Kerja Terhadap Kinerja Guru Slb Swasta Di Cirebon. Jurnal Kesehatan Masyarakat (e-Journal), 7(4), 517-524.

Armani, A. R., \& Margunani, M. (2017). Pengaruh Profesionalisme Guru, Disiplin Kerja Dan Lingkungan Kerja Terhadap Kinerja Guru Mata Pelajaran Ekonomi Di Sma Negeri SeKabupaten Sragen. Economic Education Analysis Journal, 6(1), 70-82.

Bali Sastrawan, K. (2016). Profesionalisme Guru Dalam Upaya Meningkatkan Mutu Pembelajaran. Jurnal Penjaminan Mutu, 2(2), 65. https:/ / doi.org/10.25078/jpm.v2i2.73

Barida, M., \& Muarifah, A. (2019). Perbedaan Kinerja Guru Bimbingan dan Konseling dalam Menyelenggarakan Konseling Individual Ditinjau dari Latar Belakang Pendidikan dan Pengalaman Bekerja. Jurnal Kajian Bimbingan dan Konseling, 4(1), 22. https:/ / doi.org/10.17977/um001v4i12019p022

Creasy, K. L., \& Hall, M. (2015). Defining Professionalism in Teacher Education Programs. 2(2), 2325.

Creswell, J. W. (2017). Research Design Qualitative, Quantitative, and Mixed Methods Approaches (4 ed.). SAGE Publications.

Danil, D. (2009). Upaya Profesionalisme Guru Dalam Meningkatkan Prestasi Siswa di Sekolah (Study Deskriptif Lapangan di Sekolah Madrasah Aliyah Cilawu Garut). Jurnal Pendidikan Universitas Garut, 03(01), 30-40.

Danur, D. T., \& Nurhafizah, N. (2019). Profesionalisme Guru PAUD dalam Mengembangkan Kurikulum Tingkat Satuan Pendidikan TK Berbasis Kurikulum 2013. 3(2), 715-721.

Dodillet, S., Lundin, S., \& Krüger, J. O. (2019). Constructing professionalism in teacher education. Analytical tools from a comparative study. Education Inquiry, 10(3), 208-225. https:/ / doi.org/10.1080/20004508.2018.1529527

Easton-Brooks, D., \& Davis, A. (2009). Teacher Qualification and the Achievement Gap in Early Primary Grades. Education Policy Analysis Archives, 17(15), 1-19.

Erlina, N., Syafrimen, Noor, N. M., \& Umar, J. (2016). Keterampilan Dasar Menjalankan Sesi Kaunseling Oleh Guru-Guru Kaunseling. The 4th International Conference on Islam and Higher Education (ICIHE-2016), 1-12.

Evetts, J. (2006). Short note: The sociology of professional groups: New directions. Current Sociology, 54(1). https://doi.org/10.1177/0011392106057161

Fahmi, A., \& Hariasih, M. (2016). Pengaruh Motivasi, Pengalaman Kerja dan Lingkungan Kerja Terhadap Prestasi Kerja Guru SMK Muhammadiyah 1 Ngoro Jombang. JBMP (Jurnal Bisnis, Manajemen $\mathcal{E}$ Perbankan, 2(2), 121-140. https:// doi.org/10.21070/jbmp.v2i2.1098

Farida, Pratiwi, D. D., Andriani, S., Pramesti, S. I. D., Rini, J., Wkuswanto, C., \& Sutrisno, E. (2020). Development of Interactive Mathematics E-Module Using Visual Studio. Journal of Physics: Conference Series, 1467(1), 1-11. https://doi.org/10.1088/17426596/1467/1/012017

Fenech, M., Sumsion, J., \& Shepherd, W. (2010). Promoting early childhood teacher professionalism in the Australian context: The place of resistance. Contemporary Issues 
in Early Childhood, 11(1), 89-105. https:/ / doi.org/10.2304/ciec.2010.11.1.89

Fonsén, E., \& Ukkonen-Mikkola, T. (2019). Early childhood education teachers' professional development towards pedagogical leadership. Educational Research, 61(2), 181-196. https://doi.org/10.1080/00131881.2019.1600377

George, J., Hoxby, C., Reyes, J. W., \& Welch, F. (2005). Rivkin, Hanushek, Kain (2005) - Teachers, Schools, and Academic Achievement. 73(2), 417-458.

Gluzman, N. A., Sibgatullina, T. V., Galushkin, A. A., \& Sharonov, I. A. (2018). Forming the basics of future mathematics teachers' professionalism by means of multimedia technologies. Eurasia Journal of Mathematics, Science and Technology Education, 14(5), 1621-1633. https:// doi.org/10.29333/ ejmste/85034

Her, E. H., \& Kim, S. L. (2018). Early Childhood Teachers ' Professionalism, Teaching Efficacy, and Teacher-child Interaction. 6(4), 39-44.

Idika, E. O., \& Onuoha, J. C. (2018). Influence of economics teachers' personality on secondary school students' classroom performance in public secondary schools in Nsukka local government area of Enugu state. Journal of Social Science Education, 17(3), 100-106. https:// doi.org/10.4119/UNIBI/jsse-v17-i3-1667

Igberadja, S. (2016). Effects of teachers' gender and qualification on students' performance in vocational technical education. Journal of Technical Education and Training, 8(1), 34-42.

Isari, V., Efendi, Z. M., \& Neviyarni, N. (2017). Perbedaan Latar Belakang Pendidikan Dan Masa Kerja Guru Bimbingan Dan Konseling Terhadap Pelaksanaan Layanan Bimbingan Dan Konseling Format Klasikal. Bikotetik (Bimbingan dan Konseling: Teori dan Praktik), 1(1), 21. https:/ / doi.org/10.26740/bikotetik.v1n1.p21-29

Ishak, N. M., Hasan, S. N. S., \& Syafrimen. (2003). Quality Teachers Beget Quality Studens: Inculcating Emotional Intelligence. 1-15.

Ivankova, N. V, Creswell, J. W., \& Stick, S. L. (2009). Field Methods Sequential Explanatory Design : From Theory to Practice. https://doi.org/10.1177/1525822X05282260

Jensen, P., \& Rasmussen, A. W. (2018). Professional Development and Its Impact on Children in Early Childhood Education and Care: A Meta-Analysis Based on European Studies. Scandinavian Journal of Educational Research, 0(0), 1-16. https://doi.org/10.1080/00313831.2018.1466359

Johannes. (2018). Meningkatkan Kompetensi Profesional Guru Kontextual Melalui Workshop. I(5).

Kamila, I. N. (2017). Perbedaan Kinerja Mengajar Guru Pendidikan Anak Usia Dini Ditinjau dari Latar Belakang Pendidikan. 3(1).

Kaya, V. H., \& Gödek, Y. (2016). Perspectives in regard to factors affecting the professional development of science teachers. Journal of Human Sciences, 13(2), 2625. https://doi.org/10.14687/jhs.v13i2.3769

Kholifiatin, E. N., Sutadji, E., \& Patmanthara, S. (2020). Pengaruh Masa Kerja dan Profesionalitas Guru terhadap High Order Thinking Skill Siswa SMK melalui Level Soal Ujian. 764-773.

Kunandar. (2007). Guru Profesional Implementasi Kurikulum Tingkat Satuan Pendidikan (KTSP) dan Sukses dalam Sertifikasi Guru. Rajawali Pers.

Kusmaryani, R. E., Siregar, J. R., Widjaja, H., \& Jatnika, R. (2016). Key factors in teacher professional development. 2nd Psychology and Humanity, July 2014, 704-708.

Kusumawardhani, P. N. (2017). Does teacher certification program lead to better quality teachers? Evidence from Indonesia. Education Economics, 25(6), 590-618. https://doi.org/10.1080/09645292.2017.1329405

Lee, S. W., \& Lee, E. A. (2020). Teacher qualification matters: The association between cumulative teacher qualification and students' educational attainment. International Journal of Educational Development, 77(April). https://doi.org/10.1016/j.ijedudev.2020.102218

Li, B., Zhao, W., Li, X., Zhang, G., \& Huang, D. (2010). Investigation of vibration characteristics for high speed rigid rotor of LOX/kerosene rocket engine. Advances in the Astronautical Sciences, 138(1), 329-334. 
Manning, M., Garvis, S., Fleming, C., \& Wong, G. T. W. (2017). The relationship between teacher qualification and the quality of the early childhood education and care environment. Campbell Systematic Reviews, 13(1), 1-82. https:/ / doi.org/10.4073/csr.2017.1

Marlina, Fitria, H., \& Puspita, Y. (2020). Pengaruh Pengelolaan Kelas dan Profesionalisme Guru terhadap Prestasi Belajar Siswa. 1(3), 238-246.

Mitits, L. (2018). Multilingual Students in Greek Schools: Teachers' Views and Teaching Practices. Journal of Education and e-Learning Research, 5(1), 28-36. https:// doi.org/10.20448/journal.509.2018.51.28.36

Muhadjir, N. (1992). Perencanaan dan Kebijakan Pengembangan SDM. Rake Sarasin.

Mutohar, P. M. (2013). Manajemen Mutu Sekolah. Ar-Ruzz Media.

Nairz-Wirth, E., \& Feldmann, K. (2019). Teacher professionalism in a double field structure. British Journal of Sociology of Education, 40(6), 795-808. https:/ / doi.org/10.1080/01425692.2019.1597681

Nasrun, A., Ristiyanti Tarida, A., Anselmus Sitanggang, D., \& Khadafy, A. (2018). Statistik PAUD 2018/2019 (B. Purwaka (ed.)). Pusat Data dan Statistik Pendidikan dan Kebudayaan.

Nofriyanti, Y., \& Nurhafizah, N. (2019). Etika Profesi Guru PAUD Profesional dalam Mewujudkan pembelajaran Bermutu. Pendidikan Tembusai, 3(2), 676-684.

Nolan, A., \& Molla, T. (2017). Teacher confidence and professional capital. Teaching and Teacher Education, 62, 10-18. https://doi.org/10.1016/j.tate.2016.11.004

Nurhayati, N. (2006). Faktor-faktor yang mempengaruhi profesionalisme dan kinerja guru Biologi di SMAN Kota Makassar Sulawesi Selatan. Mimbar Pendidikan, 25(4), 64-70.

Nusa, P. R. and E. I. (2020). Dampak Sertifikasi dan Pendidikan Terakhir Terhadap Kinerja Guru PAUD Di Kabupaten Ponorogo. Jurnal Pendidikan Islam Anak Usia Dini, 01(01), 27-40.

Nusran, Baharuddin, \& Nasir, M. (2018). Pengaruh Pengalaman Kerja, Pemberian Insentif dan Disiplin Kerja Terhadap Produktivitas Kerja Guru di SMA 27 Bone. YUME : Journal of Management, 1(3), 46-83.

Pahrudin, A., Syafril, S., \& Sada, H. J. (2018). Learning Content of Islamic Education Based on Multikultural in Senior High School in Bandar Lampung. Al-Tadzkiyyah: Jurnal Pendidikan Islam, 9(1), 81. https:// doi.org/10.24042/atjpi.v9i1.2614

Pallant, J. (2007). SPSS Survival Manual: A Step by Step Guide to Data Analysis Using Spss for Windows. 287.

Parlar, H., \& Cansoy, R. (2017). Examining the Relationship between Teachers 'Individual Innovativeness and Professionalism. 10(8), 1-11. https:// doi.org/10.5539/ies.v10n8p1

Permendiknas No 16 Tahun 2007 Tentang Standar Kualifikasi Akademik dan Kompetensi Guru, (2007).

Phillips, D., Mekos, D., Scarr, S., McCartney, K., \& Abbott-Shim, M. (2000). Within and beyond the classroom door: Assessing quality in child care centers. Early Childhood Research Quarterly, 15(4), 475-496. https:// doi.org/10.1016/S0885-2006(01)00077-1

Puspitasari, Y., Tobari, \& Kesumawati, N. (2021). Pengaruh Manajemen Kepala Sekolah dan Profesionalisme Guru terhadap Kinerja Guru. JMKSP (Jurnal Manajemen, Kepemimpinan dan Suvervisi Pendidikan), 6(1).

Putri Komalasari, F. (2014). Profesionalisme Guru Ditinjau Dari Pendidikan dan Latihan (Diklat) serta Pengalaman Mengajar Guru Di SMP Negeri Se-Kecamatan Delanggu Tahun 2014. Seminar Nasional Pendidikan Ekonomi dan Bisnis, November, 5-10.

Rahayu, T., Syafril, S., Othman, K. B., Halim, L., \& Erlina, N. (2018). Kualiti Guru, Isu Dan Cabaran Dalam Pembelajaran Stem. https://doi.org/10.31219/osf.io/jqcu6

Rahayu, T., Syafril, S., Pahrudin, A., Satar, I., Halim, L., \& Erlina, N. (2018). Mini Review: Improving Teachers ' Quality in STEM-based Teaching- Learning in Secondary School. i, 112. 
DOI: 10.31004/obsesi.v5i2.937

Schachter, R. E., Gerde, H. K., \& Hatton-Bowers, H. (2019). Guidelines for Selecting Professional Development for Early Childhood Teachers. Early Childhood Education Journal, 47(4), 395-408. https:/ / doi.org/10.1007/s10643-019-00942-8

Sethi, A., Schofield, S., McAleer, S., \& Ajjawi, R. (2018). The influence of postgraduate qualifications on educational identity formation of healthcare professionals. Advances in Health Sciences Education, 23(3), 567-585. https:// doi.org/10.1007/s10459-018-98145

Setiawan, R. (2017). The influence of income, experience, and academic qualification on the early childhood education teachers' creativity in Semarang, Indonesia. International Journal of Instruction, 10(4), 39-50. https:/ / doi.org/10.12973/iji.2017.1043a

Shipton, B. (2020). Police Educators' Experiences of Teaching: Detailing Differences between Teacher- and Learner-Centred Approaches. Journal of Criminal Justice Education, 31(2), 232-249. https://doi.org/10.1080/10511253.2019.1698755

Sholihah, M., Ratnasari, K., Permatasari, Y. D., Muawanah, U., \& Fajri, A. N. F. (2020). The policy of educators' certification: An effort to improve quality, qualification, and teachers' competence. IOP Conference Series: Earth and Environmental Science, 485(1). https://doi.org/10.1088/1755-1315/485/1/012130

Sintia, N., Kuswanto, C. W., \& Meriyati, M. (2019). Meningkatkan Kemampuan Sosial Anak Usia Dini dengan Model Outbound. Jurnal CARE (Children Advisory Research and Education), 6(2), 1-10. http://ejournal.unipma.ac.id/index.php/JPAUD/article/download/3939/2034

Snider, M. H., \& Fu, V. R. (1990). The effects of specialized education and job experience on early childhood teachers' knowledge of developmentally appropriate practice. Early Childhood Research Quarterly, 5(1), 69-78. https:/ / doi.org/10.1016/0885-2006(90)90007$\mathrm{N}$

Sugiyono. (2010). Metode Penelitian Pendidikan Pendekatan Kuantitatif, Kualitatif, dan R\&D. Bandung: Alfabeta.

Suwarni, S. (2011). Analisis Kebijakan Nasional tentang Jabatan Fungsional Guru dan Angka Kredit pada SMA Negeri di DKI Jakarta. ATIKAN: Jurnal Kajian Pendidikan, 1(1), $123-$ 140.

Svensson, L. G. (2006). New professionalism, trust and competence: Some conceptual remarks and empirical data. Current Sociology, 54(4). https:// doi.org/10.1177/0011392106065089

Syafril, S., Puspasari, V., Supriyadi, Pahrudin, A., Wekke, I. S., \& Aini, N. R. (2020). Psychological Effects of Interactive Multimedia Based on Scientific Approach in Science Teaching and Learning. Journal of Physics: Conference Series, 1467(1). https://doi.org/10.1088/1742-6596/1467/1/012068

Syafril, Syafrimen, Ishak, N. M., \& Erlina, N. (2017). Emotional Intelligence Profile of Prospective Teacher. Journal of Engineering and Applied Sciences, 12(7), 1677-1680.

Syafril, Syafrimen, Ishak, N. M., Erlina, N., \& Rahayu, T. (2017). Delapan Cara Pembinaan Motivasi Di Kalangan Pendidik. 00. https://doi.org/10.31219/osf.io/r7a94

Syafril, Syafrimen, Siregar, M., Atmojo, W. T., Pahrudin, A., \& Sanjaya, D. (2020). Eight Aspects of Motivational Development Among. 17(4), 15-26.

Syafril, Syafrimen, Yaumas, N. E., Ishak, N. M., Yusof, R., Jaafar, A., Yunus, M. M., \& Sugiharta, I. (2020). Characteristics and Educational Needs of Gifted Young Scientists: A focus Group Study. Journal for the Education of Gifted Young Scientists, 8(2), 947-954. https://doi.org/10.17478/JEGYS.691713

Syaifulloh, M. (2017). Analisis Profesionalisme Guru, Diklat Dan Prestasi Guru Terhadap Kualitas Pendidikan Pada Sekbin 3 Uptd Pendidikan Kecamatan Brebes Kabupaten $\begin{array}{lllll}\text { Brebes. Jurnal Pendidikan Sekolah } 17 . & \end{array}$ https://doi.org/10.30870/jpsd.v3i1.1073

Tabachnick, B. G. (n.d.). D Esigns Using Anova. 
Toh, K. A., Diong, C. H., Boo, H. K., \& Chia, S. K. (1996). Determinants of teacher professionalism. British Journal of In-Service Education, 22(2), 231-244. https:/ / doi.org/10.1080/0305763960220209

Turner, B. S. (2016). London School of Economics Talcott Parsons, Universalism and the Educational Revolution: Democracy versus Professionalism Author (s ): Bryan S. Turner Source: The British Journal of Sociology, Vol . 44, No . 1 (Mar ., 1993 ), pp . 1-24 Published b. 44(1), 124.

Ubabuddin. (2018). Profesionalisme Guru dalam Meningkatkan Kualitas Pendidikan Agama Islam Melalui Penilaian Kinerja Guru. 7(2), 20-33.

Utami, L. D., \& Kartini, K. (2017). Faktor demografis, personality traits, dan overconfidence (Survey terhadap investor saham di Yogyakarta). Jurnal Siasat Bisnis, 20(2), 181-196. https:/ / doi.org/10.20885/jsb.vol20.iss2.art6

Vartuli, S. (1999). How early childhood teacher beliefs vary across grade level. Early Childhood Research Quarterly, 14(4), 489-514. https:/ / doi.org/10.1016/S0885-2006(99)00026-5

Veisson, M., \& Kabaday, A. (2018). Exploring the preschool teachers' views on professionalism, quality of education and sustainability: International study in Estonia and Turkey. Journal of Teacher Education for Sustainability, 20(2), 5-18. https:// doi.org/10.2478/jtes-2018-0011

Wisnarni, W. (2018). Implikasi Guru Profesional Dalam Pembentukan Karakter Siswa. Tarbawi : Jurnal Ilmu Pendidikan, 14(1), 31. https:/ / doi.org/10.32939/tarbawi.v14i1.253

Woodrow, C. (2007). W ( $H$ ) Ither the Early Childhood Teacher: tensions for early childhood professional identity between the policy landscape and. 8(3), 233-243.

Yawan, R. (2016). Pengaruh motivasi kerja guru dan gaya kepemimpinan Kepsek terhadap kinerja guru SD Biak Numfor, Papua. Jurnal Pendidikan Matematika dan Sains, 4(2), 184194. https://doi.org/10.21831/jpms.v4i2.12949

Yuslam, Y., Setiani, R. E., \& Sari, A. K. (2017). Studi Tentang Kompetensi Guru PAUD Berkualifikasi Akademik Sarjana PG-PAUD Dan NonPG-PAUD di PAUD Istiqomah Sambas Purbalingga. Al-Athfal: Jurnal Pendidikan Anak, 3(2), 151. https:// doi.org/10.14421/al-athfal.2017.32-04

Yusnita, Y., Eriyanti, F., Engkizar, Anwar, F., Putri, N. E., Arifin, Z., \& Syafril, S. (2018). The Effect of Professional Education and Training for Teachers ( PLPG ) in Improving Pedagogic Competence and Teacher Performance. 3(2), 123-130. https:// doi.org/10.24042/tadris.v3i2.2701 